Ks. Arkadiusz NOCOŃ

(Roma)

\title{
POETA PORANKA I WIECZORU. HYMNY ŚW. AMBROŻEGO W LITURGII GODZIN
}

„Napełniajcie się Duchem, przemawiając do siebie wzajemnie
w psalmach i hymnach, i pieśniach pełnych ducha,
śpiewając i wysławiając Pana w waszych sercach”

(Ef 5, 18-19)

Zachęceni tymi słowami św. Pawła, jak i przykładem samego Chrystusa, który ze swymi uczniami śpiewał hymny (por. Mt 26, 30; Mk 16, 26), pierwsi chrześcijanie od samego początku chętnie uwielbiali nimi Boga. Wspomina o tym chociażby Pliniusz Młodszy w swoim słynnym Liście do cesarza Trajana z początku II wieku ${ }^{1}$, a z autorów chrześcijańskich, m.in. św. Ignacy Antiocheński ${ }^{2}$ czy Tertulian ${ }^{3}$. Z biegiem czasu twórczość hymniczna rozwijała się coraz intensywniej ${ }^{4}$, najpierw na Wschodzie ${ }^{5}$, a później i na Zachodzie, osiągając $\mathrm{w}$ średniowieczu olbrzymią liczbę ok. 30 tys. utworów (!), wydanych na przełomie XIX i XX wieku w 55 tomach ${ }^{6}$. Jeśli nawet w niektórych okresach historii dochodziło do pewnych wypaczeń w komponowaniu hymnów, które stawały się niezrozumiałą dla większości uczestników liturgii ,sztuką dla sztuki”, by przypomnieć tylko obiegową w XVII wieku opinię na ich temat: ,acces-

\footnotetext{
${ }^{1}$ Por. Plinius Minor, Epistula 96: ,soliti essent [christiani] stato die ante lucem convenire carmenque Christo quasi deo dicere". Autor używa tutaj słowa carmen, które znawcy tematyki thumaczą jako „hymn”, por. S. Cichy, Treści teologiczne hymnów w odnowionej Liturgii Godzin, „Anamnesis" 1999/2000, nr 21(2), s. 104. Należy wspomnieć, że św. Ambroży swoje hymny również nazywał carmen, por. Epistula 75a, 34, CSEL 82/3, 105: ,grande carmen istud est, quo nihil potentius".

${ }^{2}$ Por. Epistula ad Ephesios 4, 1-2, oraz Epistula ad Romanos 2, 2.

${ }^{3}$ Por. Apologeticum 39, 18; De anima 9, 4; De oratione 27; Ad uxorem III 8, 8; De carne Christi 17, 1; Adversus Marcionem V 5, 12; De exhortatione castitatis 10, 2; De spectaculis 29, 4; De virginibus velandis 17,4 .

${ }^{4}$ Historię hymnów, ich twórców, znaczenie i treści teologiczne omawia, m.in., S. Cichy (Treści teologiczne hymnów, s. 104-117).

${ }^{5} \mathrm{Na}$ temat hymnografii wschodniej w pierwszych trzech wiekach chrześcijaństwa, zob. np. Hymnes DACL VI/2 2826-2928.

${ }^{6}$ Por. Analecta hymnica Medii Aevi, ed. G.M. Dreves - C. Blume, t. 1-55, Leipzig 1886-1922, oraz Frankfurt a. M. $1962^{2}$.
} 
sit latinitas, recessit pietas"ᄁ, Kościół traktował je zawsze jako integralną i bardzo istotną część Liturgii Godzin: „Hymny bowiem bardziej niż inne części oficjum, ukazują od razu charakter poszczególnych Godzin i obchodów oraz pobudzają wiernych do pobożnego uczestnictwa w liturgii"'. Istotnie, o tym że wywołują one „uczucie pobożnego oddania (affectus pietatis), zaświadcza sam św. Augustyn opisując w Wyznaniach swoje emocje, jakie towarzyszyły mu w czasie słuchania śpiewu hymnów, ułożonych przez Ambrożego:

„Ileż razy płakałem słuchając hymnów... wstrząśnięty błogim śpiewem Twego Kościoła. Głosy te wlewały się do moich uszu, a gdy Twoja prawda ściekała kroplami do serca, parowało z niego gorące uczucie pobożnego oddania. Z oczu płynęły łzy i dobrze mi było z nimi”"

\section{I. ,WIELKI JEST TEN ŚPIEW [HYMNÓW], OD KTÓREGO NIE MA NIC POTĘŻNIEJSZEGO"10}

Właśnie Ambrożemu, twórcy łacińskiego hymnu kościelnego ${ }^{11}$ i jego obecności w aktualnej Liturgii Godzin, chcemy poświęcić naszą uwagę. Wprawdzie pierwszym autorem hymnów liturgicznych na Zachodzie był św. Hilary z Poitiers $(† 367)^{12}$, który w czasie swego wygnania na Wschodzie spotkał się z twórczością ojca hymnografii - św. Efrema (zm. 373) ${ }^{13}$, jednak poezja Galijczyka okazała się zbyt wymagająca dla przeciętnego odbiorcy, tak pod względem treści jak i zastosowanej metryki; nie wiemy więc, czy kiedykolwiek została użyta $\mathrm{w}$ liturgii ${ }^{14}$. Hilary ponadto, mimo że był równie dobrze wykształcony jak Ambroży, nie posiadał, jak się wydaje, owego geniuszu twórczego, owej artystycznej kreatywności pozwalającej ,przekładać” pojęcia teologiczne na sugestywne poetyckie obrazy. Biskupa Mediolanu słusznie więc można uważać za pierwszego hymnologa chrześcijańskiego na Zachodzie ${ }^{15}$, który poza

\footnotetext{
${ }^{7}$ Por. Cichy, Treści teologiczne hymnów, s. 104.

${ }^{8}$ Ogólne Wprowadzenie do Liturgii Godzin 173, w: Liturgia Godzin. Codzienna modlitwa Ludu Bożego, t. 1, Poznań 1982, 75.

${ }_{9}^{9}$ Augustinus Hipponensis, Confessiones IX 6, 14, CCL 27, 141, thum. Z. Kubiak: Św. Augustyn, Wyznania, Warszawa $1982^{2}, 161$.

${ }^{10}$ Ambrosius, Epistula 75a, 34, thum. P. Nowak: Ambroży z Mediolanu, Listy, t. 3: Listy 70-76 i Listy poza zbiorem. Akta Synodu w Akwilei, BOK 28, Kraków 2012.

${ }^{11}$ Por. Muza łacińska. Antologia poezji wczesnochrześcijańskiej i średniowiecznej (III-XIV/ $X V$ w.), red. M. Starowieyski, BN II 255, Wrocław - Warszawa - Kraków 2007, s. XXII.

${ }^{12}$ Por. S. Longosz, Hymny św. Hilarego i Kolumby, SACh 15 (2001) 271-292.

${ }^{13}$ Por. Leksykon liturgii, red. B. Nadolski, Poznań 2006, 524.

${ }^{14}$ Por. Muza łacińska, s. XXIII. B. Nadolski (Leksykon liturgii, s. 524), stwierdzi wprost: „Żaden z hymnów Hilarego nie wszedł do liturgii”.

${ }^{15}$ Por. C. Riggi, Lineamenti della personalità di s. Ambrogio nel ricordo agostiniano w: tegoż, Epistrophe. Tensione verso la divina armonia. Scritti di filologia patristica, Biblioteca di Scienze Religiose 70, Roma 1985, 281.
} 
komponowaniem hymnów, zaprowadził także zwyczaj ich śpiewania w czasie liturgii ${ }^{16}$. Same hymny powstały, jak się wydaje, dość przypadkowo, aby dodać ducha obrońcom jednej z mediolańskich bazylik, którą władza świecka zamierzała przekazać arianom. Biskup Ambroży zamknięty z liczną grupą wiernych w środku kościoła ułożył dla oblężonych specjalne modlitwy, proste w formie, ale bogate w treści, i co najważniejsze, zdolne w tamtej dramatycznej sytuacji, poruszyć serca i umysły. Hymny Ambrożego to zatem rezultat jego głębokiej wiary i niezwykłej wrażliwości artystycznej, to modlitwa i teologia, wyrażone w poezji i w muzyce. Biskup Mediolanu był bowiem także autorem muzyki dla swych hymnów, których zwrotki były wykonywane na przemian przez dwa chóry ${ }^{17}$. To, czego dokonał, ważne jest więc nie tylko dla liturgii, ale także dla poezji chrześcijańskiej, która w hymnach znalazła swą najbardziej naturalną i popularną formę ${ }^{18}$. Zasługą Ambrożego było także to, że sprowadził poezję do jej naturalnego środowiska, do jej „matecznika”. Na samym bowiem początku, jak wiadomo, poeci śpiewali swoje wiersze. Ambroży powrócił więc do śpiewu poezji, któremu nadał charakter chóralny, wyrażający nie tylko harmonię głosów, ale i harmonię serc, uczuć i tęsknot. Śpiewowi chóralnemu blisko jest więc zawsze do środowiska Kościoła, który z natury jest wspólnotą.

Hymny Ambrożego odniosły wielki ,sukces” wśród oblężonych obrońców świątyni również dlatego, że śpiew chóralny, w którym każdy z wykonawców znajduje jakby naturalne oparcie w drugim, wywołuje na ogół radość i podnosi na duchu. W języku włoskim wyraża to dobrze gra słów: canto corale è canto cordiale (śpiew chóralny jest śpiewem serdecznym) ${ }^{19}$.

Biskupowi Ambrożemu, jak wspomnieliśmy, udało się w hymnach znakomicie połączyć lirykę z teologia, jak jednak przystało na pasterza zatroskanego o pobożne i prawe życie swoich wiernych, nie brak w niech także pewnego moralizmu. Jego carmina miały bowiem nie tylko pomóc wiernym przeżyć kluczowe pory dnia, uwielbiając Boga sercem i ustami ${ }^{20}$, ale także zachęcać ich do dobrego postępowania. Cel tworzenia hymnów był więc na wskroś duszpasterski, a do jego realizacji Ambroży zaangażował cały swój geniusz i swą niezwykłą wrażliwość artystyczną. Wychowany według ideałów klasycznej paidei, był bowiem przekonany, że piękno odgrywa bardzo pomocną rolę $\mathrm{w}$ dobrym życiu.

Jako poeta Biskup Mediolanu dysponował wszystkim, czego potrzebuje poeta: wrażliwością artystyczną, fantazją poetycką i twórczym entuzjazmem. Jego poezja jest przy tym poezją szczerą: jej autor nie ukrywa swych myśli

\footnotetext{
${ }^{16}$ Por. F. Drączkowski, Patrologia, Pelplin - Lublin 1998, 322.

${ }^{17}$ Por. I. Biffi, Preghiera e poesia negli Inni di sant'Ambrogio e di Manzoni, Foligno 2010, 33, oraz G. Del Ton, Gli inni di Sant'Ambrogio, Como 1940, 17-18.

${ }^{18}$ Por. Ch. Mohrmann, Etudes sur le latin des chrétiens, t. 1, Roma 1961², 160.

${ }^{19}$ Por. C. Angelini, I doni del Signore, Vimodrone 1970, 30.

${ }^{20}$ Dla Ambrożego (De officiis I 45), podobnie jak dla Augustyna (Enarrationes in Ps. 148, 17), hymn z definicji jest śpiewem, za pomocą którego oddaje się Bogu cześć i chwałę.
} 
i uczuć ${ }^{21}$. Ich głębia nie przygniata jednak literackiej formy - pisze mądrze i pięknie. Jego wrogowie zarzucali mu nawet, że swymi hymnami uwodzi $\operatorname{lud}^{22}$. Mógł uwodzić: był poetą i muzykiem. I to wybitnym muzykiem ${ }^{23}$, a zdaniem niektórych, najwybitniejszym spośród wszystkich Ojców Kościoła ${ }^{24}$. Wiadomo, że wzrastał w środowisku arystokratycznym, w którym muzyka była częścią wychowania młodego człowieka, jeśli jednak jako pasterz lokalnego Kościoła z taką gorliwością propagował śpiew liturgiczny, musiał być w nim rozmiłowany i doskonale obeznany. Uczeni zwracają uwagę na jego głęboką wiedzę muzyczną i podkreślają że Ambroży wypowiada się nie tylko na temat estetyki muzycznej (jak jego uczeń Augustyn), ale zdradza także dużą znajomość samej jej techniki ${ }^{25}$.

\section{II. „ILEŻ RAZY PŁAKAŁEM SŁUCHAJĄC HYMNÓW”26}

Ile hymnów, ułożonych przez Ambrożego, mógł słyszeć Augustyn? Sam wspomina o $\mathrm{czterech}^{27}$. A ile wszystkich skomponował Biskup Mediolanu? Watpliwe, abyśmy kiedykolwiek poznali odpowiedź na to pytanie. Od VII wieku hymny kościelne nazywano bowiem powszechnie hymnami ambrozjańskimi, choć wiadomo, że nie wszystkie wyszły spod pióra Ambrożego ${ }^{28}$. Wśród uczonych od długiego czasu toczy się więc dyskusja, której nie zamknęły nawet, opracowane w 1862 r. przez Luigiego Biraghiego, trzy podstawowe kryteria autentyczności hymnów Biskupa Mediolanu, a mianowicie: zgodność hymnu z duchem twórczości Ambrożego (1), z jego słownictwem (2) i z jego stylem (3) ${ }^{29}$. Stosujące powyższe kryteria włoski uczony uznał za autentyczne 18 hymnów: 1. Splendor paternae gloriae (in aurora), 2. Iam surgit hora tertia (ad horam tertiam), 3. Nunc sancte nobis Spiritus (ad horam tertiam), 4. Rector potens verax Deus (ad horam sextam), 5. Rerum, Deus, tenax vigor (ad horam nonam), 6. Deus creator omnium (ad horam incensi), 7. Iesu, corona virginum (ad vesperas in communi virginum), 8. Intende qui regis Israel (in Natale

${ }^{21}$ Por. A. Paredi, S. Ambrogio e la sua età, Milano 1994, 468.

${ }^{22}$ Por. Ambrosius, Epistula 75a, 34 (zob. wyżej n. 10). Dłuższy fragment listu zamieściliśmy niżej przy n. 64.

${ }^{23}$ A. Amelli, Sant'Ambrogio e la musica, „Biblioteca Ceciliana” 1 (1907) 89: „Anima eminentemente musicale".

${ }^{24}$ Por. E.T. Moneta Caglio, Lo „Iubilus” e le origini della salmodia responsoriale, „Jucunda Laudatio" 15 (1976-1977) 141.

${ }^{25}$ Por. Biffi, Preghiera e poesia negli Inni di sant'Ambrogio, s. 34.

${ }^{26}$ Augustinus, Confessiones IX 6, 14, CCL 27, 141, tłum. Z. Kubiak, s. 161.

${ }^{27} \mathrm{Za}$ hymny Ambrożego Augustyn uważał następujące: Aeterne rerum conditor (Augustinus, Retractiones I 21); Iam surgit hora tertia (De natura et gratia 63, 74); Deus creator omnium (Confessiones IX 12); Intende qui regis Israel (Sermo 372, 4, 3).

${ }^{28}$ Por. B. Altaner - A. Stuiber, Patrologia, thum. P. Pachciarek, Warszawa 1990, 509.

${ }^{29}$ Por. L. Biraghi, Inni sinceri e carmi di Sant'Ambrogio, Vescovo di Milano, Milano 1862, 7. 
Domini), 9. Inluminans Altissimus (in Epiphaniis Domini), 10. Agnes beatae virginis (in sanctae Agnes virginis et martyris), 11. Hic est dies versus Dei (in die Paschae), 12. Victor, Nabor, Felix, pii (in ss. Victoris, Naboris, Felicis), 13. Grates tibi, Iesu, novas (in inventione ss. Protasii et Gervasii), 14. Apostolorum passio (in ss. Petri et Pauli), 15. Apostolorum supparem (in sancti Laurentii), 16. Amore Christi nobilis (in sancti Iohannis), 17. Aeterna Christi munera (ad laudes matutinas in communi plurimorum martyrum), 18. Aeterne rerum conditor (ad galli cantum).

Nie wszyscy jednak podzielali stanowisko L. Biraghiego. G.M. Dreves, na przykład, uważał za autentyczne czternaście hymnów ${ }^{30}$, A. Steier - dwanaście ${ }^{31}$, M. Simonetti - dziewięc ${ }^{32}$, a U. Sesini - sześśc ${ }^{33}$. Kryteria przyjmowane przez poszczególnych uczonych, ograniczające na ogół liczbę hymnów uważanych za autentyczne, były różne. Niektórzy, na przykład, przywiązywali duże znaczenie do struktury i metryki hymnów, twierdząc, że Ambroży miał upodobanie w liczbie 8. Istotnie, każdy z jego hymnów ma osiem zwrotek, a wersy osiem sylab. Cyfra osiem nawiązuje ponadto do ósmego dnia tygodnia (octava dies) i symbolizuje Zmartwychwstanie Chrystusa, oraz nową erą chrześcijaństwa. Dla wspomnianych badaczy było więc niemożliwe, aby Biskup Mediolanu zrezygnował z tego upodobania: wykluczyli zatem hymny, które nie odpowiadały temu kryterium. Aktualnie na osiemnaście hymnów, przypisywanych Ambrożemu przez L. Biraghiego, uczeni są prawie że zgodni, aby jako autentyczne uznać tylko pięć ${ }^{34}$, a mianowicie: Deus creator omnium, Aeterne rerum conditor, Iam surgit hora tertia, Intende qui regis Israel, Splendor paternae gloriae. Na ich korzyść miałoby świadczyć nie tylko podobieństwo języka i stylu, ale także wiarygodne świadectwa z epoki, odnoście autora i czasu ich powstania ${ }^{35}$. O tym, że dyskusja nie jest jednak zamknięta, najlepiej świadczy fakt, że redaktorzy opublikowanego w 1994 r. tomu dzieł poetyckich Ambrożego $^{36}$, który zamknął wydanie Opera omnia Biskupa Mediolanu, zamieścili w nim trzynaście hymnów ${ }^{37}$.

${ }^{30}$ Por. G.M. Dreves, Aurelius Ambrosius, «der Vater des Kirchengesanges», Amsterdam 1968 (przedruk z 1893), 83.

${ }^{31}$ Por. A. Steier, Untersuchungen über die Echtheit der Hymnen des Ambrosius, Jahrbücher für Klassische Philologie. Supplementband 28, Leipzig 1903, 634 i 638.

${ }^{32}$ Por. M. Simonetti, Studi sull'innologia popolare cristiana dei rimi secoli, t. 4, Roma 1952 , 341-484.

${ }^{33}$ Por. U. Sesini, Poesia e musica nella latinità cristiana dal III al X secolo, ed. G. Vecchi, Torino 1949, 55.

${ }^{34}$ Por. G. Banterle, Sant'Ambrogio. Opere poetiche e frammenti: Inni-Iscrizioni-Frammenti, w: Sancti Ambrosii Episcopi Mediolanensis Opera (= SAEMO), t. 22, ed. G. Banterle - G. Biffi I. Biffi - L. Migliavacca, Milano - Roma 1994, 11.

${ }^{35}$ Por. tamże.

${ }^{36}$ Por. tamże, n. 33.

${ }^{37}$ Także I. Biffi w wydanej w 2010 r. książce (Preghiera e poesia negli Inni di sant'Ambrogio, s. 36-118), zamieszcza trzynaście hymnów Ambrożego. 
Pozostawiając nierozstrzygniętą sprawę autorstwa hymnów i czasu ich powstania (ok. 386 r.), wokół którego również toczy się dyskusja ${ }^{38}$, chcemy tylko zauważyć, że w aktualnie zatwierdzonym łacińskim wydaniu Liturgiae horarum $^{39}$ znajduje się osiem hymnów, uznawanych za hymny św. Ambrożego, zaś w polskiej Liturgii Godzin - siedem ${ }^{40}$. Są to: Boże Stwórco wszystkich rzeczy (I nieszpory niedzieli I tygodnia), Nieśmiertelny blasku Ojca (Jutrznia poniedziałku I tyg.), Przyjdź o Zbawicielu świata (Godzina czytań Adwentu od 17 grudnia), Niebiańskim blaskiem pogodny (Godzina czytań okresu wielkanocnego), $W$ godzinie męki Chrystusa (Godzina przedpołudniowa okresu wielkanocnego), To dzień narodzin męczeńskich (Jutrznia wspomnienia św. Agnieszki, 21 stycznia), Męka Bożych Apostołów (Jutrznia uroczystości św. Apostołów Piotra i Pawła, 29 czerwca $)^{41}$.

W naszym opracowaniu chcielibyśmy przyjrzeć się bliżej dwom najwcześniejszym hymnom Ambrożego, wobec których uczeni nie wysuwają zastrzeżeń, zarówno co do ich autentyczności, jak i integralności ${ }^{42}$. Są to: Aeterne rerum conditor i Deus creator omnium ${ }^{43}$. Obydwa warte są uwagi także dlatego, iż regularnie są odmawiane przez kapłanów (i wielu świeckich), i że najpełniej objawiają poetycki geniusz Biskupa Mediolanu.

\section{AETERNE RERUM CONDITOR}

Hymn ten znajduje się obecnie w niedzielnej jutrzni I i III tygodnia, w 3 i 4 tomie Liturgii Godzin w j. łacińskim (Liturgia Horarum) ${ }^{44}$, obejmujących Okres Zwykły (tygodnie 1-34). Tłumaczenie polskie, autorstwa o. Placyda Galińskiego OSB ${ }^{45}$, pochodzi z polskiego wydania Monastycznej Liturgii Go-

${ }^{38}$ Obydwie te kwestie, tzn. autorstwa i czasu powstania hymnów, omawia szczegółowo G. Banterle we Wprowadzeniu do włoskiego wydania Hymnów Biskupa Mediolanu, por. SAEMO 22, 11- 22.

${ }^{39}$ Dzieje Liturgii Godzin na przestrzeni wieków i jej teologia, zostały szeroko omówione w: „Mirabile Laudis Canticum”. Liturgia Godzin: Dzieje i teologia. Księga pamiatkowa dedykowana ks. bp Stefanowi Cichemu, Biskupowi Legnickiemu, Przewodniczqcemu Komisji do Spraw Kultu Bożego i Dyscypliny Sakramentów Episkopatu Polski, red. H.J. Sobeczko, Opole 2008.

${ }^{40}$ Por. Cichy, Treści teologiczne hymnów, s. 105. W wydaniu polskim Liturgii Godzin hymn Aeterne rerum conditor został zastapiony innym, autorstwa P. Galińskiego, por. Leksykon liturgii, s. 53.

${ }^{41}$ Por. Cichy, Treści teologiczne hymnów, s. 115-116, przypis 8.

42 Problem integralności (skażenia) dotyczy także tych hymnów, które powszechnie uznawane są za hymny Ambrożego. M. Simonetti (Studi sull’innologia, s. 386-387), na przykład, uważa za skażoną 1. zwrotkę hymnu Intende qui regis Israel, podobnego zdania jest także U. Sesini (Poesia e musica nella latinità cristiana, s. 55).

${ }^{43}$ Por. Banterle, Sant'Ambrogio. Opere poetiche e frammenti, SAEMO 22, 17.

${ }^{44}$ Por. Liturgia Horarum iuxta Ritum Romanum. Editio typica altera, t. 3 (Tempus per annum, Hebdomadae I-XVII), Liberia Editrice Vaticana 1986, 598-599, 857-858, oraz t. 4 (Tempus per annum, Hebdomadae XVIII-XXXIV), Liberia Editrice Vaticana 1987, 548-549, 807-808.

${ }^{45}$ Por. F. Małaczyński, Prace nad polskim przekładem Liturgii Godzin, AK 75 (1983) t. 101, 29; 
$d z \mathrm{in}^{46}$. Dla porównania, przytoczyliśmy także tłumaczenie Zygmunta Kubiaka (kursywą) $)^{47}$.

Aeterne rerum conditor powstał wraz z kilkoma innymi hymnami, aby, jak wspomnieliśmy, podtrzymać na duchu broniących mediolańskiej świątyni i ożywić ich modlitwę w różnych porach dnia. W tym wypadku chodzi o porę tuż przed świtem, „porę, w której pieją koguty” (Ad gallicinium). Napisany prostym i wpadającym w ucho dymetrem jambicznym (nazwanym później metrem ambrozjańskim), podzielony na czterowierszowe zwrotki, w których akcent słowny zgadza się na ogół $\mathrm{z}$ akcentem wierszowym ${ }^{48}$, uchodzi za najbardziej oryginalny utwór poetycki starożytnego chrześcijaństwa łacińskiego ${ }^{49}$ i, zdaniem niektórych, sam jeden wystarczyłby, aby uważać Ambrożego za wybitnego poetę ${ }^{50}$ :

\section{Przekład P. Galińskiego}

\begin{tabular}{|c|c|}
\hline $\begin{array}{l}\text { 1. Aetérne rerum cónditor, } \\
\text { noctem diémque qui regis, } \\
\text { et témporum das témpora, } \\
\text { ut álleves fastídium. }\end{array}$ & $\begin{array}{l}\text { 1. O przedwieczny Stwórco świata, } \\
\text { Który rządzisz dniem i noca, } \\
\text { Przez nie dzielisz czas na doby, } \\
\text { By nie znużył brakiem zmiany. }\end{array}$ \\
\hline $\begin{array}{l}\text { 5. Præco diéi iam sonat, } \\
\text { noctis profúndæ pérvigil, } \\
\text { noctúrna lux viántibus } \\
\text { a nocte noctem ségregans. }\end{array}$ & $\begin{array}{l}\text { 5. Już odzywa się w ciemności } \\
\text { Czujny strażnik wschodu słońca, } \\
\text { Który swoim głosem wiedzie } \\
\text { Wędrujących nocną porą. }\end{array}$ \\
\hline $\begin{array}{l}\text { 9. Hoc excitátus lúcifer } \\
\text { solvit polum calígine; } \\
\text { hoc omnis errónum chorus } \\
\text { vias nocéndi déserit. }\end{array}$ & $\begin{array}{l}\text { 9. Po nim budzi się jutrzenka } \\
\text { I uwalnia z mroków niebo; } \\
\text { Pierzcha wszelka moc szatana, } \\
\text { Bo skończona jego władza. }\end{array}$ \\
\hline $\begin{array}{l}\text { 13. Hoc nauta vires cólligit } \\
\text { pontíque mitéscunt freta; } \\
\text { hoc, ipse Petra Ecclésiæ, } \\
\text { canénte, culpam díluit. }\end{array}$ & $\begin{array}{l}\text { 13. Żeglarz siły odzyskuje, } \\
\text { Bo widnieją morskie brzegi, } \\
\text { A wstrząśnięty pianiem ptaka, } \\
\text { Płacze Piotr nad swoją winą. }\end{array}$ \\
\hline
\end{tabular}

\section{Przekład Z. Kubiaka}
Wieczysty rzeczy Stworzycielu, Ty, który dniem i noca rzadzisz, Ty, co odmieniasz pory czasu, Aby nam ulżyć w trudach życia! Już pieje dnia radosny zwiastun, Który w głębokiej nocy czuwa. Światło wśród mroku dla wędrowców, Światto dzielace noc od nocy.

Wołaniem kura przebudzona
Jutrzenka nocny mrok rozprasza,
A cała zgraja błędnych duchów
Przestaje ludziom czynić szkodę.
Żeglarz z otucha ster ujmuje,
Fale się morza cichsze ściela.
Styszą wołanie kura, Kościót-
Opoka płacze grzechów swoich.

Cichy, Treści teologiczne hymnów, s. 105; J. Janicki, Sens i rola hymnów, AK 75 (1983) t. 101, 33-46.

${ }^{46}$ Por. Monastyczna Liturgia Godzin, t. 3 (Okres zwykły, tygodnie I-XVII), Città del Vaticano 1985, 666-667, oraz t. 4 (Okres zwykły, tygodnie XVIII-XXXIV), (miejsca i daty wydania nie podano), s. 602-603. Jak już wspomnieliśmy (zob. przypis 39) w 3 i 4 tomie Liturgii Godzin. Codziennej modlitwy Ludu Bożego wydanej w j. polskim, hymn Ambrożego został zastąpiony innym hymnem, autorstwa P. Galińskiego.

${ }^{47}$ Por. Muza łacińska, s. 28-30.

${ }^{48}$ Por. tamże, s. XXIII i s. 28.

${ }^{49}$ Por. J.L. Chalet, Richesse spirituelle d'un hymne d'Ambroise: ,,Aeterne rerum conditor”, MD 173 (1988) 61.

${ }^{50}$ Por. Biffi, Preghiera e poesia negli Inni di sant'Ambrogio, s. 43. 
[kierując się kryterium zwięzłości dwie następne zwrotki hymnu zostały w Liturgii Godzin opuszczone ${ }^{51}$ ]

[17. Surgamus ergo strenue: gallus iacentes excitat, et somnolentos increpat, gallus negantes arguit.

21. Gallo canente, spes redit, aegris salus refunditur, mucro latronis conditur, lapsis fides revertitur].

25. Iesu, labántes réspice et nos vidéndo córrige; si réspicis, lapsus cadunt fletúque culpa sólvitur.

29. Tu, lux, refúlge sénsibus mentísque somnum díscute; te nostra vox primum sonet et vota solvámus tibi.
25. Teraz spójrz na chwiejnych, Jezu, I powstrzymaj przed upadkiem; Swoim wzrokiem oddal grzechy, Pomóż błędy obmyć łzami.

29. Światłem jesteś, więc zabłyśnij

I z umysłów usuń senność,

Aby dzisiaj nasze modły

Najpierw Ciebie wysławiały.
[17. Powstańmy teraz petni mocy! Już kur leżacych ze snu budzi, Wota, omdlatych napomina, Tych, którzy przecza, przekonuje.

21. Nadzieja wraca z jego śpiewem I zdrowie krzepi ciała chore. $W$ pochwę się kryje miecz mordercy Kto zrozpaczony - znowu ufa].

Spójrz, Jezu, na tych, co upadli. Spojrzeniem swoim nas podźwignij. Gdy na nas patrzysz, gina grzechy I we tzach wina się rozplywa.

Ty świattość jesteś. O, zabłyśnij Zmysłom i mroki duszy rozprosz! Ciebie niech sławi głos nasz pierwszy, Ciebie niech sławi pieśń ostatnia!

[Ostatnia zwrotka nie występuje w oryginale ${ }^{52}$ ]

33. Sit, Christe, rex piíssime, 33. O Chryste, Królu łagodny,

tibi Patríque glória

Tobie i Ojcu Twojemu

Cum Spíritu Paráclito,

Z Najświętszym Duchem pociechy

in sempitérna sæcula. Amen.

W powyższej kompozycji, która, jak wspomnieliśmy, przeznaczona była dla nocnego oficjum, a dokładniej, dla uwielbienia Boga w ostatniej części nocy, tuż przed wschodem słońca, zwraca uwagę zdolność Ambrożego do wyrażenia językiem poezji otaczającej go natury. Pomogła mu w tym niewątpliwie jego wrażliwość artystyczna, podatna na kontemplację zjawisk przyrody: profunda nox (głęboka noc), nocturna lux (światło wśród mroku), ponti freta mitescentes (uspokajające się morskie fale), lucifer solvens polum caligine (jutrzenka rozpraszająca nocny mrok), etc. Ambroży nie jest jednak tylko wyrafinowanym piewcą natury (jak chociażby Wirgiliusz, którego dalekie echa przebrzmiewają $\mathrm{w}$ tym hymnie ${ }^{53}$ ), za opisem zjawisk przyrody kryje się bowiem obecność Boga, a sama natura jest dla Ambrożego metafora, tłem do teologicznej refleksji.

Hymn rozpoczyna się inwokacją do Przedwiecznego Stwórcy, który wszystkim rządzi i kieruje (ww. 1-4), dlatego następujące po sobie pory dnia i nocy, nie są rezultatem jakieś ślepej, anonimowej siły, lecz przejawem

${ }^{51}$ Por. Te decet hymnus. L'innario della „Liturgia Horarum”, ed. A. Lentini, Città del Vaticano 1984, 14.

${ }^{52}$ Por. tamże.

${ }^{53}$ Por. Biffi, Preghiera e poesia negli Inni di sant'Ambrogio, s. 38. 
opatrzności i dobroci Boga, który dzięki zmianom czasu (w. 3) zdejmuje z ludzi nieznośny ciężar monotonii (w. 4). Sama zaś nocna pora, w której wykonywany jest hymn, nie jest dla Ambrożego jedynie zjawiskiem natury czy wycinkiem czasu, uprzywilejowanym dla działania szatańskiej mocy (w. 11), ale przede wszystkim metafora, obrazującą stan ludzkiego serca, narażonego na działanie ciemnych sił fizycznych i duchowych. Z jednej strony, cały hymn jest więc westchnieniem do światła, które za chwilę pojawi się na horyzoncie i pokona nocne ciemności, z drugiej zaś, cała tak sugestywnie wyrażona w nim tęsknota za słońcem, jest niczym innym, jak obrazem duszy tęskniącej za Światłem, które rozproszy jej mroki i lęki. W takiej właśnie scenerii, kończącej się nocy, pojawia się w hymnie jego bohater liryczny, czyli... piejący kogut (w. 5). Uczeni zwracają uwagę na ten odważny i udany zabieg artystyczny, choć należy dodać, że w czasach Ambrożego kogut nie był zwykłym ptakiem domowym, a ,instytucją publiczną”(!). Jego pianie spełniało bowiem rolę wieży zegarowej, wyznaczającej poszczególne części nocy ${ }^{54}$. Jeśli jednak Ambroży uczynił z koguta bohatera swego hymnu, to nie dlatego, że darzył go sympatią (choć istotnie kogut pojawia się dosyć często w jego pismach ${ }^{55}$ ), ani dlatego, że jego pianie było nieodzownym elementem nocnego krajobrazu Niziny Padańskiej, tylko dlatego, że w świecie chrześcijańskim kogut był doskonałym obrazem i figurą Mistycznego Koguta - Chrystusa (Gallus Mysticus), który budzi ospałą ludzkość, budzi ludzkie sumienia, podobnie jak obudził sumienie Piotra (ww. 15-16) ${ }^{56}$. Dobroczynne skutki piania koguta, w przyrodzie i w sercu człowieka, ukazywane są od trzeciej zwrotki hymnu: obudzona przez niego gwiazda poranna (lucifer) rozprasza nocne ciemności (ww. 9-10), złe duchy (inni erronum chorus tłumaczą jako „bandy zbirów”), zaprzestają swej niecnej działalności (ww. 11-12), żeglarz nabiera ducha (w. 13), uspokajają się morskie bałwany (w. 14) ${ }^{57}$, krzywoprzysięzca obmywa łzami swoją winę (w. 16), chorzy nabierają siły (w. 22), zrozpaczeni nadziei (w. 21), a upadli wiary (w. 24).

${ }^{54}$ Noc w czasach Ambrożego dzielono, według piania koguta, na trzy części: gallicinium primum (pierwsze pianie koguta), o północy, zamykało pierwszą część nocy i rozpoczynało część drugą - conticinium (czas ciszy i spoczynku). Ostatnią, trzecią część nocy - gallicinium rozpoczynało drugie pianie koguta, tu przed świtem, por. Angelini, I doni del Signore, s. 32.

55 Por. Ambrosius, Hexameron V 24, 88-89. Na temat obecności koguta w pismach Ojców Kościoła, a zwłaszcza w pismach Ambrożego, który w hymnie Aeterne rerum conditor rozwinął symbolikę koguta czyniąc z niego obraz Chrystusa-Światła, zob. G.M. Pintus, Storia di un simbolo: il gallo, „Sandalion” 8-9 (1985-1986) 243-267.

${ }^{56}$ Por. Mt 26, 69-75.

${ }^{57}$ Pojawiający się dość często w pismach Ambrożego motyw żeglarza i morza jest zaskakujący u autora, który zamieszkiwał w centrum Niziny Padańskiej, dlatego komentatorzy widzą w nim symbol człowieka zmagającego się z bezkresem wszechświata, por. Banterle, Sant'Ambrogio. Opere poetiche e frammenti, SAEMO 22, 33. 
Kolejne zwrotki hymnu rozpoczynają się inwokacją do Jezusa (ww. 25-28):

„Teraz spójrz na chwiejnych, Jezu, / i powstrzymaj przed upadkiem; / Swoim wzrokiem oddal grzechy, / pomóż błędy obmyć łzami”.

Wymieniając wcześniej zagrożenia i nieszczęścia, jakie niesie ze sobą noc, Ambroży podkreślił wyraźnie grzech zdrady. Przypominając jednak ewangeliczną scenę zaparcia się Piotra (ww. 15-16), kierował się nie tylko wrażeniem, jakie ona na nim wywarła, ale przede wszystkim chciał poprzez nią ukazać tak bliską mu teologię łez i przebaczenia. Zdaniem Inosa Biffiego, spośród wszystkich Ojców Kościoła, Ambroży jest być może tym, który najmocniej ufa w wielkość Bożego miłosierdzia ${ }^{58}$.

Ostatnia, ósma zwrotka hymnu, napisana przez Ambrożego (ww. 29-32), jest tą, ku której zmierzały wszystkie poprzednie, będące jednym wielkim wołaniem o światło. Właśnie teraz światło to otrzymuje swe prawdziwe imię - Chrystusa, Światłości świata, wobec którego każde inne światło jest tylko bladym zwiastunem i symbolem.

\section{SPLENDOR PATERNAE GLORIAE}

To kolejny hymn Ambrożego, związany z budzącym się dniem (In aurora). W aktualnej Liturgii Godzin odmawiany jest podczas poniedziałkowej jutrzni I i III tygodnia, w 3 i 4 tomie Liturgii Godzin w j. łacińskim ${ }^{59}$, oraz w poniedziałkowej jutrzni I tygodnia, w 3 i 4 tomie Liturgii Godzin w j. polskim $^{60}$. Ponieważ w hymnie powtarzają się pewne motywy, które wstępowały już w poprzednim (Ad gallicinium), np. słońce rozpraszające nocne ciemności obrazuje Chrystusa, który pokonuje grzech i zwątpienie, etc., postanowiliśmy zrezygnować ze szczegółowej analizy, podkreślając jedynie jego bardzo silny wydźwięk antyariański. Widoczny jest on już w pierwszych słowach hymnu: Splendor paternae gloriae, de luce lucem proferens (Nieśmiertelny blasku Ojca, w Tobie źródło jest świattości, ww. 1-2). Zauważmy, że jeśli Credo Nicejskie używa w odniesieniu do Syna określenia lumen de lumine, to Ambroży podkreśla zdecydowanie, że Syn jest nie tylko Światkem, które pochodzi od Ojca, ale jest także fons luminis, czyli źródłem wszelkiego światła ${ }^{61}$. Nie wyklucza to oczywiście, ani nie pomniejsza, roli pozostałych osób Trójcy Świętej w dziele stworzenia i zbawienia, a jedynie podkreśla bardzo mocno Bóstwo Chrystusa. Zdaniem niektórych komentatorów, do tego właśnie hymnu miałby się odnosić Ambroży występując z pewną dumą przeciw Auksencjuszowi ${ }^{62}$

\footnotetext{
${ }^{58}$ Por. Biffi, Preghiera e poesia negli Inni di sant'Ambrogio, s. 42.

${ }^{59}$ Por. Liturgia Horarum, t. 3, s. 571 i 816-817, oraz t. 4, s. 519 i 764.

${ }^{60}$ Por. Liturgia Godzin. Codzienna modlitwa Ludu Bożego, t. 3 (Okres zwykły, tygodnie I-XVII), Poznań 1987, s. 582-583, oraz t. 4 (Okres zwykły, tygodnie XVIII-XXXIV), Poznań 1988, 538-539.

${ }^{61}$ Por. Banterle, Sant'Ambrogio. Opere poetiche e frammenti, SAEMO 22, 35.

${ }^{62}$ Por. tamże.
} 
i wspominając jeden jedyny raz tak wyraźnie o swoich hymnach ${ }^{63}$ :

„Mówią, że lud jest zwiedziony także śpiewami moich hymnów: z pewnością tak jest, również tego nie zaprzeczam. Wielki jest ten śpiew, od którego nie ma nic potężniejszego. Cóż bowiem potężniejszego od wyznania Trójcy, która codziennie jest wielbiona ustami całego ludu? Na wyścigi wszyscy starają się wyznawać wiarę, umieją za pomocą wierszy wielbić Ojca i Syna i Ducha Świętego. Stali się więc nauczycielami ci wszyscy, którzy ledwie mogli być uczniami, ${ }^{\circ}$.

Wydźwięk antyariański, jaki towarzyszy hymnowi Splendor paternae gloriae, właściwie od pierwszego aż do ostatniego wersu, sprawia, że niektórzy zwykli go nazywać „Soborem Nicejskim napisanym wierszem”,

\section{DEUS, CREATOR OMNIUM}

Hymn ten odmawiany dzisiaj w czasie I nieszporów niedzieli I i III tygodnia, w 3 i 4 tomie Liturgii Godzin w j. łacińskim ${ }^{66}$ i j. polskim ${ }^{67}$, obejmujących Okres Zwykły (tygodnie 1-34). Dla porównania (kursywą), przytoczyliśmy także inne thumaczenie polskie, tym razem autorstwa Edwarda Porębowicza ${ }^{68}$.

Uznawany za najbardziej znany i popularny z hymnów Ambrożego ${ }^{69}$, przypomina nie tylko forma, ale i źródłem inspiracji hymn Aeterne rerum conditor, obydwa bowiem ubierają w szatę poezji i przemieniają w modlitwę zmieniającą się porę dnia ${ }^{70}$. W tym wypadku, chodzi o porę, w której zapalaja się pierwsze wieczorne światła (Ad horam incensi). Hymn oddaje tak doskonale nastrój tej chwili, że zadaniem niektórych, śmiało może stać obok największych tekstów poetyckich, podejmujących ten temat. Bohaterem utworu nie jest tutaj jednak zachodzące słońce, ale pewne egzystencjalne napięcie, jakie w tym specyficznym momencie pojawia się między Bogiem, Władca wszechświata, a słabym, zmęczonym i kuszonym człowiekiem, który mimo to zdolny jest także do uwielbienia, miłości i zachwytu ${ }^{71}$.

Już w traktacie poświęconym dziewicom Biskup Mediolanu nauczał, że uroczyste modlitwy dziękczynne powinny być odmawiane, m.in.: po przebu-

${ }^{63}$ Por. Ambroży z Mediolanu, Listy 70-76 i Listy poza zbiorem. Akta Synodu w Akwilei, thum. P. Nowak, BOK 28, Kraków 2012, 63, przypis 35. Zdaniem redaktora i thumacza w Hexameronie III 1, 5 i 5, 23, Biskup Mediolanu wspomina tylko ogólnie o śpiewach liturgicznych.

${ }^{64}$ Ambrosius, Epistula 75a, 34, CSEL 82/3, 105, thum. P. Nowak, BOK 28, 93.

${ }^{65}$ Por. I. Biffi, Il concilio di Nicea tradotto i versi, OsRom 148 (2008) nr 92 (19 IV), s. 5.

${ }^{66}$ Por. Liturgia Horarum, t. 3, s. 589 i 849, oraz t. 4, s. 539 i 799.

${ }^{67}$ Por. Liturgia Godzin, t. 3, s. 559 i 788, oraz t. 4, s. 515 i 744.

${ }^{68}$ Por. Muza łacińska, s. 30-31.

${ }^{69}$ Por. Biffi, Preghiera e poesia negli Inni di sant'Ambrogio, s. 57.

${ }^{70}$ Por. tamże.

${ }^{71}$ Por. Banterle, Sant'Ambrogio. Opere poetiche e frammenti, SAEMO 22, 43. 
dzeniu, przed wyjściem z domu, przed spożyciem posiłku, po posiłku, gdy zapala się lampę wieczorna, oraz przed udaniem się na spoczynek ${ }^{72}$. Hymn Deus, creator omnium, ułożony został przez Ambrożego właśnie jako modlitwa wieczorna, towarzysząca zapalaniu lampy (Ad horam incensi), aby w porze, gdy gaśnie światło dzienne, chrześcijanin mógł prosić Boga o światło duchowe pozwalające mu bezpiecznie przetrwać noc.

\section{Przekład z Liturgii Godzin}

1. Deus, creátor ómnium, políque rector, véstiens diem decóro lúmine, noctem sopóris grátia.

5. Artus solútos ut quies reddat labóris úsui mentésque fessas állevet luctúsque solvat ánxios.

9. Grates perácto iam die et noctis exórtu preces, voti reos, ut ádiuves, hymnum canéntes sólvimus.

13. Te cordis ima cóncinat, te vox canóra cóncrepet, te díligat castus amor, te mens adóret sóbria.

17. Ut, cum profúnda cláuserit diem calígo nóctium, fides tenébras nésciat et nox fide relúceat.
1. Boże, Stwórco wszystkich rzeczy,

Który władasz przestworzami, Jasnym blaskiem dnie ozdabiasz, Darem snu napełniasz noce.

5. Niech spoczynek nam przywróci Sprawność znużonego ciała, Myśl odświeży, a sumienie Niech ukoi łaską skruchy.

9. Za miniony dzień składamy

Dzięki na początku nocy.

Ty nam pomóż swoją łaską

Być wiernymi Tobie, Boże.

13. Ciebie niechaj dusza sławi, Ciebie pieśnią głos wychwala, Ciebie trzeźwy umysł wielbi, Ciebie czyste serce kocha.

17. Gdy głęboki mrok pochłonie Blaski światła słonecznego, Niech mu wiara się nie podda, Lecz jaśnieje wśród ciemności.

\section{Przekład E. Porębowicza}

Twórco wszechświata, Boże nasz

Dzierżacy kręgu ziemi ster,

Dzień przyoblekasz w jasny strój,

A noc utulasz taska snu.

Znużone członki by się znów

Skrzepity na jutrzejszy trud,

By ocknat się zmęczony duch,

By go opuścit smętny lęk.

Modlą się po zamknięciu dnia,

$W$ momencie, gdy nastaje noc;

Wspomóż nas winnych spetnić ślub,

Ten oto podnosimy hymn.

Niech Cię serc naszych wielbi pieśn

I na Twa chwate chórem brzmi,

Niech mitość czysta Tobie gra

I niech uwielbi trzeźwa myśl.

Gdy noc nad ziemia zamknie się,

W krag jq otuli gęsty cień,

Niechaj nie zaćmi wiary mrok,

Skroś cieniów niech jej płonie blask.

W Liturgii Godzin opuszczono dwie następne zwrotki ${ }^{73}$

[21. Dormíre méntem ne sinas,

dormíre cúlpa nóverit:

castos fides refrígerans

somni vapórem témperet.

25. Exúta sénsu lúbrico te córdis álta sómnient, nec hóstis ínvidi dolo pavor quiétos súscitet].

29. Christum rogémus et Patrem Christi Patrísque Spíritum:
[21. Nie dozwól myśli zapaść w sen, Niech go nie spęta żaden grzech; Czystym ochtoda będzie on

I nie dopuści sennych mar.

25. Wyzuty z lubieżności zmyst,

O Tobie serce niechaj śni,

Zawistny i podstepny wróg

Niech strachem nie nawiedza go].

29. Prośmy Chrystusa i Ojca

I Ducha od Ojca i Syna:

\footnotetext{
${ }^{72}$ Por. Ambrosius, De virginibus III 4, 18.

${ }^{73}$ Por. Te decet hymnus, s. 11.
} 
unum potens per ómnia

fove precántes, Trínitas.

Amen.
O Trójco, jedyna mocy ze wszystkich

Wspomagaj, kto Ciebie wzywa ${ }^{74}$.

Amen.

W omawianym już przez nas hymnie Aeterne rerum conditor, zwróciliśmy uwagę, że ciemność i noc postrzegane były przez Ambrożego jako uprzywilejowana pora dla działalności złych duchów. W hymnie Deus, creator omnium, który wprowadza chrześcijanina w nadchodzącą noc, autor zachęca go więc, aby świadom pułapek jakie czekają na niego ze strony Złego, powierzył się $\mathrm{z}$ ufnością opiece Stwórcy. Podobnie jak Aeterne rerum conditor, hymn rozpoczyna się więc inwokacją do Boga Stwórcy wszechświata (Deus, creator omnium), zaczerpniętą z Księgi Machabejskiej (por. 2 Mac 1, 24). Podobieństw w obydwu hymnach jest zresztą więcej, np. podziw dla Stwórcy, którego mądrość kieruje światem, którego piękno wyraża się w naturze i którego dobroć obdarza człowieka niezliczonymi darami. Jednym z tych darów jest dla Ambrożego sen, o którym pisze z wdziękiem, wymieniając jego dobrodziejstwa (ww. 4-8). Kończący się dzień jest jednak przede wszystkim okazją, aby podziękować Bogu i uwielbić Go za otrzymane od Niego łaski (ww. 9-16). Kolejne wersy hymnu to seria błagań, aby noc, niebezpieczna pora, przeżyta była na modlitewnym czuwaniu, bez upadków i ulegania podszeptom szatana (ww. 17-28). Sama zaś noc, widziana jest tutaj jakby ciemna powłoka, która przykrywa „blaski światła słonecznego” i zagraża światłu wiary (ww. 17-20). Autor wierzy jednak, że dzięki pomocy Boga człowiek może przezwyciężyć duchowe ciemności (w. 20). Potrzebne jest jednak czyste serce, które nawet podczas snu pozostaje z Nim w łączności (ww. 25-26). Ambroży wyraźnie nawiązuje tutaj do jednego z wersetów Pieśni nad Pieśniami: Ego dormio sed cor meum vigilat (Ja śpię, lecz moje serce czuwa) (Pnp 5, 2). Nie jest to przypadek odosobniony, jeśli chodzi o poetykę hymnu i użyte w nim obrazy. Biskup Mediolanu chętnie odwołuje się do Pisma Świętego, np. do Księgi Psalmów: „O Boże mój, Panie, jesteś bardzo wielki! Odziany we wspaniałość i majestat, światłem okryty jak płaszczem" (Ps 104,1-2). Nie brak też odwołań do literatury klasycznej, np. do Wergiliusza, którego echa (np. purpureum lumen $^{75}$, dulcis sopor ${ }^{76}$, etc.) przebrzmiewają w hymnie ${ }^{77}$. Komentatorzy pod-

${ }^{74}$ Przekład ostatniej zwrotki pochodzi od autora artykułu. Końcowy werset hymnu: fove precantes, Trinitas, niezwykłej urody, jak podkreślają filologowie, należałoby także ich zdaniem rozumieć i tłumaczyć bardziej „tkliwie”, np: „przyjmij z matczyną troską, tych, którzy się do Ciebie uciekają (tych, którzy Cię błagają)”. Używając charakterystycznego i „delikatnego” czasownika fovere, Ambroży miałby prosić Trójcę Świętą, aby niczym troskliwa matka przytulająca do piersi swe dziecko, przyjęła wszystkich, którzy z ufnością powierzają się Jej opiece przed nadchodzącą noca, por. G. Del Ton, Gli inni di S. Ambrogio, Venegono Inferiore 1940, 51.

${ }^{75}$ Por. Vergilius, Aeneis VI 640.

${ }^{76}$ Por. Ps-Vergilius, Ciris (Appendix Vergiliana) 314.

${ }^{77}$ Por. Biffi, Preghiera e poesia negli Inni di sant'Ambrogio, s. 60. 
kreślają, że w utworze Ambrożego można jednak spotkać wyrażenia oryginalne, urzekające swym pięknem, by wspomnieć tylko ową pieśń, sławiącą Boga, która wydobywa się „, głębi ludzkiego serca” (cordis ima, w. 13), czy też wiarę, która dla Biskupa Mediolanu jest nie tylko cnotą i relacją z Bogiem, ale i ,światłem jaśniejącym w ciemnościach" (nox fide reluceat, w. 20).

Ostatnie wersy hymnu, to żarliwe wyznanie trynitarne, z bardzo wyraźnym akcentem antyariańskim (ww. 29-32). Biskup Mediolanu zwyczajowo kończył w ten sposób swoje carmina, starając się ugruntować wśród ludu nicejskie wyznanie wiary. Uczeni podkreślają, że to jeden z najbardziej zaskakujących aspektów w jego życiu, a mianowicie, że dochodząc do chrztu świętego i do urzędu biskupa, posiadł również tak nieskazitelną i precyzyjną doktrynę chrystologiczną i trynitarną ${ }^{78}$.

$$
* * *
$$

Ambroży z Mediolanu, jak twierdzą znawcy tematu, był jedynym z wielkich pisarzy łacińskich pierwszych wieków chrześcijaństwa, który był zarazem wielkim prozatorem i wybitnym poetą ${ }^{79}$. Był też jedynym, którego proza i poezja były podziwiane, zarówno przez współczesne, jak i późniejsze pokolenia $^{80}$. Nikt lepiej od niego nie potrafił włączyć łacińskiego chrześcijaństwa w biblijny zwyczaj uwielbiania Boga hymnami. Nie obarczając zbytnio swej poezji filozofia, jak poeci wschodni, by wspomnieć tylko Grzegorza z Nazjanzu, Biskup Mediolanu słuchał przede wszystkim głosu serca, dzielącego, jak na Pasterza Kościoła przystało, troski i niepokoje swoich wiernych. Próżno więc szukać w jego hymnach odniesień do mitów czy filozofii pogańskiej, skoro każdy ich wers ma przybliżać wiernych do jedynej Prawdy ${ }^{81}$, o czym w Wyznaniach wspomni sam Augustyn: „Recordatus sum veridicos versus Ambrosii tui" ${ }^{82}$. Rzeczywiście, Biskup Mediolanu miał niezwykły dar przekładania na język poezji i muzyki wielkiej refleksji teologicznej swojego wieku (,,złotego wieku" w teologii), czyniąc ją nie tylko głębszą, ale i piękniejszą $^{83}$. Na podstawie dwóch przytoczonych hymnów, mogliśmy się przekonać, jak za pomocą niewielu wersów o rzadko spotykanym pięknie, potrafił ukazać rzeczywistość kosmiczną i ludzką, czyniąc z niej podłoże do teologicznych rozważań. Mogliśmy podziwiać z jak niebywałą naturalnością, właściwą po-

${ }^{78}$ Por. tamże, s. 62.

${ }^{79}$ Por. J. Fontaine, Ambroise de Milan. Hymnes, Paris 1992, 77.

${ }^{80}$ Por. tenże, Prose et poésie: l'interférence des genres et des styles dans la création littéraire d'Ambroise de Milan, w: Ambrosius Episcopus. Atti del Congresso internazionale di studi ambrosiani (Milano 1974), ed. G. Lazzati, t. 1, Milano 1976, 140.

${ }_{81}^{81}$ Por. Riggi, Lineamenti della personalità di s. Ambrogio, s. 307 i 313.

${ }^{82}$ Augustinus, Confessiones IX 12, 32, CCL 27, 151.

${ }^{83}$ Por. G.M. Vian, Un piccolo libro denso e felice, w: Biffi, Preghiera e poesia negli Inni di sant'Ambrogio, s. 10. 
etom w chwilach największej inspiracji, porusza się między różnorodnymi tematami, stanowiącymi tło dla wyraźnego w jego pieśniach chrystocentryzmu. Istotnie, Biskup Mediolanu, bardziej niż którykolwiek z Ojców Kościoła, podkreślał chrystocentryzm wiary. Na nim opierało się jego duszpasterstwo i jego teologia. Ten chrystocentryzm miłosierny, bo tak należałoby go nazwać, jest też najbardziej oryginalną i urzekającą cechą jego poezji ${ }^{84}$. Niezwykła natomiast umiejętność Ambrożego, który z każdej pory doby potrafił uczynić modlitwę i hymn uwielbienia dla Stwórcy, pozwala nam też łatwiej zrozumieć Petrarkę, wstającego po północy, aby recytować hymny na cześć Boga ${ }^{85}$.

THE POET OF DAWN AND DUSK.

THE HYMNS OF ST AMBROSE IN THE LITURGY OF THE HOURS

\section{(Summary)}

Following the example of the Lord, who frequently sang hymns with his disciples, and encouraged to sing by St Paul, the early Christians praised God in music and song. The first Latin hymns were composed by Hilary of Poitiers. Their metrical complexity and content discouraged their liturgical use by the Church. Thus, St. Ambrose of Milan is considered the first „official” Latin hymnodist. He composed several hymns, still used in the Liturgy of the Hours, which were musicated by himself. These hymns come from the particular circumstances of the Arian controversy and derive, in the main, from the necessity of encouraging ,orthodox" Christians in their defence of the Basilica Porziana in Milan. They were designed to guide their prayer at different times of the day. The Author's textcritical analysis of two of these hymns - Aeterne rerum conditor, sung at dawn (in gallicinium) and Deus, creator omnium, sung at dusk as the lamps were lit (ad horam incensi) - well testifies to the literary and pastoral genius of the Bishop of Milan as he transforms the complex theological reflection of his time into poetry and music, while not only retaining the integrity of the depth of that reflection but also enhancing its aesthetic profile by drawing on a repertoire of images based on the parallelism of cosmic reality and human reality. St Ambrose's corpus of hymns, together with his prose works, was admired both by his contemporaries and by successive generations. They promoted the flowering of a merciful Christocentricity which, according to the experts, is the most original and attractive feature of his poetry. As is clearly seen in the hymns received into the Divine Office, Ambrose's singular ability effectively to stimulate the soul to prayer through a powerful and insuperable lyrical inspiration, is capable literally of transforming the daily hours into songs of praise, and explains Petrarch's habit of rising during the night to sing hymns to the Lord.

\footnotetext{
${ }^{84}$ Por. Biffi, Preghiera e poesia negli Inni di sant'Ambrogio, s. 21.

${ }^{85}$ Por. Angelini, I doni del Signore, s. 34.
} 
